\title{
An Old Uighur Receipt Document Newly Discovered in the Turfan Museum
}

Abstract: This article introduces an Old Uighur document, which had been excavated seemingly in the Bezeklik Caves and was recently re-discovered in the Turfan Museum. It is supposed to be a receipt for the payment of the poll tax (qupcïr) of the Mongol period, and to be closely related to the Old Uighur administrative orders of the St. Petersburg collection (SI 6544).

Key words: Old Uighur document, Turfan, receipt, taxation, qupchir, Mongol Empire

\section{Introduction}

The Old Uighur texts unearthed from the Bezeklik Caves (Turfan, Xinjiang, PRC) have been the target of the academic researchers of Central Asian history and Old Turkic philology. In particular, the Turfan Bureau of Cultural Relics excavated a huge number of the texts in 1980-1981. ${ }^{1}$ Among them, five Old Uighur Manichaean letter correspondences from the tenth and eleventh century are considered the most noteworthy materials for the history of the religion. ${ }^{2}$ Also, other texts excavated simultaneously, most of which are the Buddhist fragments, are now under cataloguing through the international cooperation. $^{3}$

(C) Li Gang 李剛, Minzu University of China, Academia Turfanica; Matsui Dai 松井太, Graduate School of Letters, Osaka University.

Acknowledgment: This work was supported by JSPS KAKENHI Grant Numbers 26300023, 26580131, 26284112, and by the Asian History Research Aid (2014:6) of JFE $21^{\text {st }}$ Century Foundation.

${ }^{1}$ TULUFAN DIQU WENWU GUANLISUO 1985.

${ }^{2}$ TXM; YOSHIDA, MORIYASU 2000.

${ }^{3}$ Cf. Matsui 2009b, 42. 
Besides them, six Old Uighur secular documents had been earlier brought under the preservation in the Turfan Museum: five of them are Old Uighur administrative orders of compulsory requisition for fodder; ${ }^{4}$ and another is a document concerning the transaction of Buddhist portraits. ${ }^{5}$ So far as reported, all of the six should have been excavated in front of one of the Bezeklik Caves in October $1974,{ }^{6}$ and accordingly they should have been given inventory numbers beginning with 74TB ("[19]74, T[urfan], B[ezeklik]"). However, the precise inventory numbers for them were not informed in the previous scholarly publications, and afterward these texts got substantially inaccessible in the Turfan Museum. ${ }^{7}$

Quite recently, the Turfan Museum has conducted reorganization of their collections and rediscovered those six Old Uighur documents. Actually they had been preserved under a single inventory number 81TB60:6, mistaken as a group. Considering the information in the former publication, the Turfan Museum has now given them new inventory numbers beginning with 74TB. ${ }^{8}$

More notably, they are accompanied by another Old Uighur fragment thus far unpublished. It is highly plausible that the fragment should be excavated in October 1974, on the same occasion with the other six documents. Thus the Turfan Museum has given this fragment a new inventory number as 74TB60:6-2. In this paper, we would present the edition of this brand-new fragment.

The text is written on the sheet of dark yellow paper $(14.7 \mathrm{~cm}$ in length and $11.5 \mathrm{~cm}$ in width) and in the so-called cursive Uighur script which may well date the text to the Mongol period. The upper part of the text is faded for any reason, and rather difficult to decipher (see Pl. 1).

\footnotetext{
${ }^{4}$ Geng 1980; cf. UmemURa 1981; Kurban 1984. For the latest revised edition, see MatSUI 2009a.

${ }^{5}$ Dolkun, UMemura, Moriyasu 1990; UMEMURa 1990, 177-182.

${ }^{6}$ Geng 1980; Dolkun, Umemura, Moriyasu 1990, 13-14; Umemura 1990, 177; cf. KURBAN 1984, 105, for another date of excavation as early 1976.

${ }^{7}$ Cf. Matsui 2009a, 340, fn. 1.

${ }^{8} 74 \mathrm{~TB} 60: 6-3,74 \mathrm{~TB} 60: 6-4,74 \mathrm{~TB} 60: 6-5,74 \mathrm{~TB} 60: 6-6$ for the four fragments of the five administrative orders, and 74TB60:6-1 for the document of the transaction of Buddhist portraits.
} 


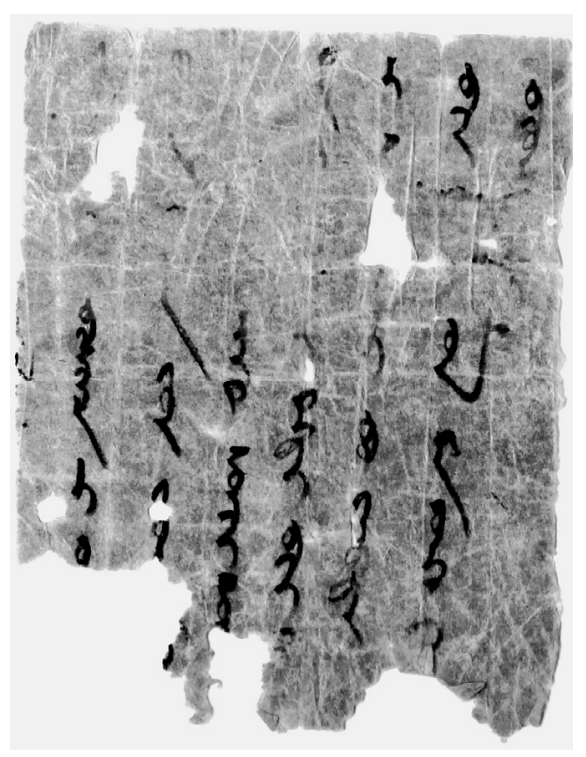

Pl. 1

74TB60:6-2 (Turfan Museum)

Reproduced by the Permission of the Academia Turfanica

\section{Text}

1 [ ] $](..) \mathrm{L}[$

2 y[ yïl] bešinč ay 'W[

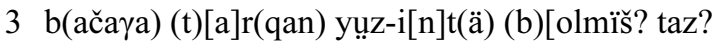

4 ( ) iki stïr qu(p)[č̈ir kümüš

5 -tä (b)[ir stï]r tägdi bir s(tïr) [qupčïr? kümüšs?-

6 -ni s[anap] [alï]p bo yanuḍ [berdimiz bo tamya/nišan]

7 biz-[nin](g) ol män ongš(a)y [

8 bit(i)[dim]

\section{Translation}

${ }_{2}$ The $[\ldots .$.$] year, the fifth month, [on] the [.... day].$

3-4 Of two stïr of the [qupčirr-silver] that B[olmïš-Taz?] of Bačaya-tarqan's century [should pay?], [one stïr] has arrived (= we received). ${ }_{4-5}[\mathrm{We}$ ?] counted and received (this) one [stïr of the qupčir-silver], and ${ }_{5-6}\left[\right.$ we issued] this receipt. ${ }_{6-7}[$ This seal/signature] is ours. ${ }_{7} \mathrm{I}$, Ongšay [.....], ${ }_{8}$ Wrote (this receipt). 


\section{Analytic Reconstruction of the Context}

It is rather difficult to reconstruct the whole context of the document, though we would present the text and translation above, based on the analysis as follows.

The first keyword is ${ }_{3} y u z-i[n] t(\ddot{a})$ "of/in the century (of)." Uig. yuz $\sim y \ddot{u} z$ "hundred" can be interpreted as "a century, a unit of one hundred households" to correspond to Mong. jayun (>jayud (pl.)) and Chin. 百戸 bai-hu. The following locative suffix $-i[n] t(\ddot{a}) \sim-$ intä $\left(=-Y N T^{\prime}\right)$ is well restorable in comparison with other attestations of yuz-intä in the Uighur documents SI 6544 (SI Uig. $14=$ USp 53(1-4)) and *U9251: the former consists of four administrative orders for compulsory requisition issued to a single person named Bolmïš-Taz, who belonged to a century of one named Bačaya-tarqan and delivered a horse at each of the requisition orders to convert into a part of the qupčir-tax imposed on $\mathrm{him}^{9}$; and the latter should be a fragment of the record of the grain for land tax, collected by six decuries (Uig. on $\sim$ on- $\ddot{i}=$ Chin. 十戸 shi-hu, unit of ten households) under a century headed by one named Quduqun. ${ }^{10}$

The second keyword is ${ }_{6}$ yanud $\sim$ yanut "something given in return for or in place of." Even though it is written as if $Y^{\prime} P D^{\prime} Z$, it should be read as $Y^{\prime} N W D=y a n u d(\sim y a n u t)$ : we find the similar stroke for yanud in the attestations of yanud bitig "a receipt document" (SUK Mi18 4 and U 5960 6 6) ${ }^{11}$ Here yanud alone must be interpreted as "a receipt." 12

These two keywords may well lead us to suppose that this document was a receipt (yanud $\sim$ yanut) for the payment of any tax or labor service imposed on a person/persons belonging to a century (yüz). Taking into consideration such a function of our document, we can further supplement the context.

Line 1 of our document is almost illegible except for a few strokes including $-L-$, and the ductus of the writing is smaller than that of the lines $2-8$. Thus, we would be allowed to consider that the document substantially begins with line 2, which apparently concerns the date of the document: other ex-

${ }^{9}$ MATSUi 2015b, 63-64.

${ }^{10}$ MATSUi (forthcoming).

${ }^{11}$ Matsui 2005a, 28-36; MAtsui 2015a, 102-103.

${ }^{12}$ In an unpublished document *U9326 (T III M 253), we find another attestation of yanud to stand alone for "a receipt." This document has been lost from the Berlin Collection during the Second World War, and is now available only in the photograph taken by late Prof. Reşid Rahmeti ARAT during 1933-1938. We are deeply grateful to Prof. Osman Fikri SERTKAYA (Istanbul) for his kind permission to investigate the photograph. 
amples of the Old Uighur receipt document (yanut bitig) mentioned above also begin with their date. The beginning of line 2 should be restored as either $y$ [ïlan yïl] "the Serpent year" or $y[$ [unt yïl] "the Horse year," the definite date of which will be argued below. 'W[....] after bešinč ay "the fifth month" should be any of $(\ddot{u})[\check{c}] \sim \ddot{u} \check{c}$ "three," $o[n] \sim o n$ "ten" or $o[t u z] \sim o t u z$ "thirty," evidently concerning the day of issue.

The expression ${ }_{5} t a ̈ g d i$ (past tense) < v. täg- "to reach, to arrive at" should be interpreted as "was paid, was delivered"13 and suggest that the sender of this receipt (yanud $\sim$ yanut) did receive something, which should have been described in the preceding text and be related with ${ }_{4} i k i$ stïr "two stïr." Uig. stïr was a unit of weight (ca. 40 grams) and then a currency denomination equal to the value of the silver of the same weight. And the stroke following siki stïr is written as $X W().[\ldots]$. From the context, we dare to restore it as $q u(p)[c \ddot{c}$ r kümüšs] "the qupčir-silver": Uig. qu(p) [čirr] qupčïr ( Pers. qupčūr < Mong. qubčiri) is a notorious poll tax installed on the Eurasian-wide under the Mongol rule, and was to be paid in silver cash. ${ }^{14}$ And we may note that the combination qupčir kümüš is also attested in several administrative orders. ${ }^{15}$

The locative suffix ${ }_{5}-T^{\prime}$ ' $\left.=-t a /-t a ̈\right)$, however, does not allow us to interpret that ${ }_{4} i k i$ stïr qu(p) [čir kümüš] "two stïr of the qup[čir-silver]" wholly arrived at the sender of this receipt. Therefore, we would tentatively restore ${ }_{5}(b)$ [ir $s t i] r$ "one stïr" in the illegible part following the locative -tä, and consider "[one stïr] of two stïr of the qupc̈̈r-silver" as the received material: in other words, this receipt was issued at the partial payment for the qupčir-tax, and "two stïr (iki stïr)" was the annual burden on a person belonging to the century.

Comparing with the other examples of Old Uighur receipts (yanud yanut bitig), we can restore the following context, which confirms the transaction of the silver cash and issue of this receipt: ${ }_{5} b i r$ s(tïr) "one stïr" just after tägdi may lend support for our restoration of the preceding (b) [ir stï]r; in the Old Uighur sale contracts we frequently find the combination sanap al- $(<\mathrm{v}$. san"to count" and al- "to take") for transaction, ${ }^{16}$ and then we can restore ${ }_{6}$ [anap] [alï]p in the lacuna before bo yanud [berdimiz] "[we issued] this receipt." Even though any seal (tamya) or signature (nišan) is not visible on the extant

\footnotetext{
${ }^{13}$ E.g., $3 \mathrm{Kr} 30 \mathrm{c}=\mathrm{USp} 121,{ }_{2}[. . \ddot{u} \ddot{u}]($ r) bilä iki šĭy tarïy tägdi "together with [X] of millet, two $\check{s i} \ddot{\gamma}$ of wheat arrived (= was paid)"; U5960v = MATSUI 2005, 31-33 and MATSUI 2015a, 102.

${ }^{14}$ MATSUi 2005b, 74-76, 78.

$15 *$ U9252(a) = MATSUi 2014, B5 $;$; *U9259 = MATSUi 2014, 619, C5 $5_{2} ; *$ U9255 = MATSUI 2014, 619, C6 ${ }_{1}$; *U9188(b) = VOHD 13,22, Nr. $470=$ MATSUI 2014, C10.

${ }^{16}$ YAMADA 1963, 45-46; YAMADA 1967, 98-99.
} 
manuscript, we may restore either of them in the end of line 6. ${ }_{7}$ Ongš $(a) y$ should be the name or title of the scribe: it seems derived from Chinese, but its origin remains unclear. ${ }^{17}$

Here, we consider the name of the leader of the century, which should be written before ${ }_{3} y \ddot{u} z$-intä. Though fading into less legible, it can be restored as $P\left({ }^{\prime} \check{C}^{\prime} X^{\prime}\right)(T)\left[{ }^{\prime}\right] R\left(X^{\prime} N\right)=b($ ačaya) (t) $[a] r(q a n)$. In SI 6544 mentioned earlier, we find the same name Bačaya-tarqan, who was a leader of a century. ${ }^{18}$ And the ductus of the handwriting of our document is, even though not identical, rather similar to that of three of SI 6544 (= Matsui 2015b, B1, B2, B4). Now we can consider our document and SI 6544 as contemporary and mutually related, and Bačaya-tarqan in these texts as one and the same person. If our identification is the case, we may furthermore restore another personal name Bolmï̌s-Taz in the damaged part below yüz-intä, as he appears in SI 6544: in fact, a part of the round stroke for $P$ - is slightly visible, and it might belong to (b) $[$ olmï̌s].

The "Sheep year (qoyn yïl)" of SI 6544 has been dated to the 己未 ji-wei "ji-Sheep" of 1259 CE. ${ }^{19}$ Consequently, we can offer two plausible date of our document from either $y$ [ïlan yïl] "the Serpent year" or $y$ [unt yïl] "the Horse year": the former would fall on the 丁已 ding-si "ding-Serpent" of $1257 \mathrm{CE}$, and the latter on the 戊午 $w u$-wu "wu-Horse" of $1258 \mathrm{CE}$. Even though we should take into account the possibility of dating twelve years earlier/later than those candidates, these dates may well tally with the socio-economic situation in the Old Uighur history that the qupčir-tax was later integrated into other labor services, at the latest before the Chaghataid domination from the late 1320 's. $^{20}$

\section{Conclusive Remark}

Through the analysis above, we can now recognize that the brand-new document should be a receipt for the partial payment of the qupcïr-tax, and that it concerns the same century (yüz) of a named Bačaya-tarqan, which is mentioned in the four Uighur administrative orders SI 6544 of 1259 CE. Thus,

${ }^{17}$ It is unlikely that Uig. ongšay here should be related to Pers. $W N K \check{S} A Y=\bar{u} n g \check{a} \bar{a} y$ $Y W N K \check{S} A Y=y \bar{u} n g \check{s} \bar{a} y$, which are corrupted forms of $W A N \check{S} Y=$ wānšay $\sim W Y N \check{S} A Y=$ winš̄a $y<$ Mong. 'WYNŠ' $Y=$ önšai < Chin. 元帥 yuan-shuai “marshal." Cf. PELliot 1963, 858; TMEN IV, Nrn. 1762, 1935; SugIYAMA 1987, 32-33.

\footnotetext{
${ }^{18}$ MATSUi 2015b, 63-64.

${ }^{19}$ Matsui 2014, 617-618; Matsui 2015b, 62, 64-65.

${ }^{20}$ MATSUI 2014, 624-625.
} 
we have five Old Uighur documents belonging to a contemporary period of the mid-thirteenth century. These documents deserve to be further analyzed in comparison with the other secular texts, concerning the qupcïr-tax or other taxes and labor services.

\section{References}

DOLKUN Kämbiri 多魯坤=閶伯爾 and UMEMURA Hiroshi 梅村坦 and MORIYASU Takao 森安 孝夫 1990: “Uiguru-bun bukkyō sonzō juryō meirei monjo kenkyū” ウイグル文佛教尊像 受領命令文書研究 [A Study on the Uyghur Order Document of Receiving Buddhist Portraits]. Ajia Afurika gengo bunka kenkyū アジア・アフリカ言語文化研究 [Journal of Asian and African Studies] 40, 13-34.

GENG Shimin 耿世民 1980: “Jijian huiguwen wenshu yishe” 幾件回鶻文文書譯釋 [Edition of Some Uigur Documents]. Wenwu 文物 1980-5, 83-84.

KURBAN Weli 庫爾班=外力 1984: “Tulufan chutu de wu-jian huiguwen wenshu” 吐鲁番出土 的五件回鶻文文書 [Five Uigur Documents Unearthed from Turfan]. Zhongguo minzu guwenzi yanjiu 中國民族古文字研究 [Studies on the Ancient Scripts of Nationalities in China]. Beijing: Zhongguo shehui kexue chubanshe, 105-113.

MATSUI Dai 松井太 2005a: “Uiguru-bun keiyaku monjo kenkyū hosetsu shi-dai” ウイグル文 契約文書研究補説四題 [Four Remarks on the Uigur Contract Documents]. Studies on the Inner Asian Languages 20, 27-64.

MATsui Dai 2005b: "Taxation Systems as Seen in the Uigur and Mongol Documents from Turfan: An Overview." Transactions of the International Conference of Eastern Studies 50, 67-82.

MATSUI Dai 2009a: “Bezeklik Uigur Administrative Orders Revisited.” In: Studies in Turkic Philology: Festschrift in Honour of the $80^{\text {th }}$ Birthday of Professor Geng Shimin. Ed. by Zhang Dingjing and Abdurishid Yakup. Beijing: Minzu University Press, 339-350.

Matsui Dai 2009b: "Recent Situation and Research Trends of Old Uigur Studies." Asian Research Trends (New Series) 4, 37-59.

Matsui Dai 2014: "Dating of the Old Uigur Administrative Orders from Turfan". In: VIII. International Turcology Congress (30 September - 04 October 2013 - Istanbul) Book of Papers, vol. IV. Ed. by Mustafa Özkan and Enfel Doğan. Istanbul: Istanbul University, 611-633.

MATSUi Dai 2015a: "Eski Uygur hukuk belgelerinde geçen borun ve borunluq üzerine". In: Eski Türkçeden Çağdaş Uygurcaya: Mirsultan Osman'ın Doğumunun 85. Yılına Armağan. Ed. by Aysima Mirsultan, Mihrban Tursun-Aydin and Erhan Aydin. Konya: Kömen, 89-106.

MATSUI Dai 松井太 2015b: “Ko-uiguru-go gyōsei mreiei monjo ni 'mienai' yarurigu” 古ウイ グル語行政命令文書に「みえない」ヤルリグ [Unwritten Yarlï in the Old Uigur Administrative Orders]. Jinbun shakai ronsō 人文社會論叢 [Studies in the Humanities] 33, $55-81$.

Matsui Dai (forthcoming): “Onï 'Decury' in the Old Uigur Administrative Orders.” Türk Dilleri Araştırmaları 24 [2014], in press.

Pelliot, Paul 1963: Notes on Marco Polo, vol. II. Paris: Imprimerie Nationale. 
SugIYAMA Masa'aki 杉山正明 1987: “Seireki 1314-nen zengo Dai-gen-urusu seikyō wo meguru shō sakki” 西暦 1314 年前後大元ウルス西境をめぐる小札記 [Where Were the Western Borderlands of the Dai-ön Ulus around 1314 A.D.?] Seinan ajia kenkyū 西南アジ ア研究 [Bulletin of the Society for Western and Southern Asiatic Studies, ] 27, 24-56.

SUK = YAMADA Nobuo 山田信夫 1993: Sammlung uigurischer Kontrakte, 3 vols. Ed. by Juten Oda et al. Suita (Japan): Osaka University Press.

TMEN = DOERFER, Gerhard 1963-1975: Türkische und mongolische Elemente im Neupersischen, 4 vols. Wiesbaden: Franz Steiner.

TULUFAN DIQU WENWU GUANLISUO 吐魯番地區文物管理所 1985: “Baizikelike qianfodong yizhi qingli jianji” 柏孜克里克千佛洞遺趾清理簡記 [Brief Report of the Excavation of the Ruins of the Bezeklik Caves]. Wenwu 文物 1985-8, 49-65.

TXM = 柳洪亮 LIU Hongliang (ed.) 2000: Tulufan xinchu monijao wenxian yanjiu 吐魯番新 出摩尼教文獻研究 [Studies in the New Manichaean Texts Recovered from Turfan]. Beijing: Kexue chubanshe.

UMEMURA Hiroshi 梅村坦 1981: “Torufan-ken tenrankan tenji uiguru-bun kōmonjo” 吐魯番 縣展覧館展示回鶻文公文書 [Uyghur Official Documents Displayed in the Turfan Museum]. In: Nakajima Satoshi sensei koki kinen ronshū 中嶋敏先生古稀記念論集 [Papers in Honour of Professor Satoshi Nakajima on His $70^{\text {th }}$ Birthday], vol. II. Tokyo: Kyūko shoin, 45-66.

UmemuRA Hiroshi 1990: "Uyghur Manuscripts Preserved in the People's Republic of China". In: Documents et archives provenant de l'Asie Centrale. Ed. by Haneda Akira. Kyoto: Dōhōsha, 175-186.

USp = RADLOFF, Wilhelm 1928: Uigurische Sprachdenkmäler . Ed. by Sergei Malov. Leningrad: Akademie der Wissenschaften der USSR.

VOHD 13, 22 = RASChMANN, Simone-Christiane 2009: Alttürkische Handschriften 13, Dokumente, teil 2. Stuttgart: Franz Steiner.

YAMADA Nobuo 山田信夫 1963: “Uiguru-bun baibai keiyakusho no shoshiki” ウイグル文賣 買契約書の書式 [Forms of Sale-Contract Note in Uigur Documents]. In: Chūō ajia kodaigo bunken 中央アジア古代語文獻 [Buddhist Manuscripts and Secular Documents of the Ancient Languages in Central Asia] (Monumenta Serindica VI). Kyoto: Hōzōkan, 29-62, +1 pl.

YAMADA Nobuo 1967: "Uigur Documents of Sale and Loan Contracts Brought by Ōtani Expeditions. Appendix: The Forms of the Uigur Documents of Sale Contracts". Memoirs of the Research Department of the Toyo Bunko 23 [1964], 71-118, +pls. 1-4.

YOSHIDA Yutaka 吉田豊 and MORIYASU Takao 森安孝夫 2000: “Bezekuriku shutsudo sogudo-go uiguru-go manikyōto tegamibun” ベゼクリク出土ソグド語・ウイグル語マ 二教徒手紙文 [Manichaean Sogdian and Uighur Letters Recently Unearthed in Bezeklik, Turfan]. Studies on the Inner Asian Languages 15, 135-178. 